\title{
Acknowledgements for the second edition
}

While I would like to extend my gratitude to everyone mentioned in the acknowledgements in the first edition, this new edition provides me with an opportunity to say a few additional 'thank you's.

I would like to start with Gillian Leslie, who commissioned this new edition and who identified American independent cinema as a key subject for Edinburgh University Press, which over the past few years has published some excellent studies on the topic. As always, she was very patient with me (especially as I turned out to be a few months late in submitting the manuscript) and as usual she was a great pleasure to work with on the details of the book. I would also like to thank Richard Strachan for also being extremely patient with me and for overseeing yet another one of my books on independent film, Rebecca Mackenzie for helping me choose and designing the wonderful cover of the book, Eddie Clark for managing the book's production process and Ralph Footring for his painstaking copy-editing job, which improved the manuscript vastly.

Many thanks to Anne Hurault Paupe and Céline Murillo, editors of the special issue of the Revue française d'études américaines (no. 136) under the title 'Et le cinéma indépendant?', as well as Hélène Le Dantec, the journal's editor in chief, for granting me permission to use some extracts from my article 'American Independent Cinema in the Age of Convergence', published as part of that issue in 2013.

As always, my colleagues in the Department of Communication and Media at the University of Liverpool have been a great source of support and inspiration and I would like to thank them all, especially the Head of the Department, Kay Richardson, and my new partner in crime in teaching film and media studies, Gary Needham, who reviewed some of the new case studies that appear in this edition. Lydia Papadimitriou read drafts of all the new material and offered me invaluable advice and feedback, as did Rigas Goulimaris, who checked some of 
the material I had to update throughout the book, while Jennifer Jones helped with aspects of the research for the new material. A special thank you to all of you.

As always, I would like to thank my parents, Panayiotis and Christina, my brother, Leonidas, and the rest of my family and friends in Greece, especially Panayiotis Koutakis and Alkisti Charsouli, as well as Harris Tlas, Annalies McIver, Paul Shaughnessy, Yolanda Akil Perez, Ben Howarth and Joanne Whiteside in the UK.

I have dedicated this book to my wife, Siân Lincoln, and my son, Roman Tzioumakis, both of whom have been the greatest source of happiness in my life! But I would like to close these acknowledgements by giving a mention to all those scholars who have done work on aspects of American independent cinema and whose work has influenced my own in productive ways. The majority of them were only 'names' back in 2006 when this book was first published. Eleven years later I have the great fortune to call most of these people friends. In no particular order: Warren Buckland, Peter Krämer, Chris Holmlund, Justin Wyatt, Thomas Schatz, Hilary Radner, Janet Staiger, Patricia Zimmermann, Alisa Perren, Tino Balio, Matthew Bernstein, the late Jim Hillier, Frederick Wasser, Julia Hallam, Phil Drake, Claire Molloy, Claire Perkins, Linda Badley, Michele Schreiber, James Lyons, Steve Neale, Denise Mann, Kathleen McHugh, Janet Wasko, J. J. Murphy, Michael Z. Newman, Sarah Sinwell, B. Ruby Rich, James Schamus, Murray Smith, Chuck Kleinhans, R. Barton Palmer, Peter Stanfield, Brian Taves, Glyn Davis, Chuck Tryon, Hayley Trowbridge, John Berra, Sherry B. Ortner, Annette Insdorf, Betsy McLane, Peter Lev, Greg Merritt, Rob Stone, Diane Carson, Steve Rawle, Rona Murray, Mary Erickson, Doris Baltruschat, Mark Gallagher, James Macdowell, Cynthia Baron, Christina Lane, R. Colin Tait, Nolwenn Mingant, Paul McDonald and of course Geoff King - great many thanks to all of you! Here is to continue studying and debating independence in American cinema! 